\title{
Fibroblast Growth Factor Receptor 2
}

National Cancer Institute

\section{Source}

National Cancer Institute. Fibroblast Growth Factor Receptor 2. NCI Thesaurus. Code C17411.

Fibroblast growth factor receptor $2(821 \mathrm{aa}, \sim 92 \mathrm{kDa}$ ) is encoded by the human FGFR2 gene. This protein plays a role in heparin-dependent fibroblast growth factor signaling. 